\title{
Inga OLEKSIUK
}

Szkoła Główna Handlowa, Warszawa

\section{Granice społecznej tolerancji}

\section{Kierunki zmian w świetle rozwoju nowych mediów}

W społeczeństwie, w którym wolność wypowiedzi odgrywa priorytetowe znaczenie, różnorodność źródeł informacji splata się z pluralizmem poglądów i form ludzkiej ekspresji. Jednocześnie konstytucyjnie zagwarantowana wolność słowa umożliwia kształtowanie własnego światopoglądu w poczuciu indywidualnego charakteru dokonywanych wyborów. Są to podstawowe przesłanki dla rozwoju wielokulturowych społeczeństw.

Funkcje, jakie spełnia wolność słowa w państwach demokratycznych wiążą się m.in. z ochroną, którą prawo przyznaje poglądom nie znajdującym powszechnej aprobaty ${ }^{1}$. Jeśli przyzwolenie większości dla określonej wypowiedzi, byłoby uznane za przesłankę sine qua non gwarancji wolności wypowiedzi to omawiana wartość miałaby wyłącznie deklaratywny charakter. Narzucenie jednostce określonego systemu wartości w sferze społeczno-obyczajowych i indywidualnych aspektów życia lub ograniczanie dostępu do wypowiedzi kwestionujących dominujące w tej sferze normy jest równie problematyczne, jak stosowanie cenzury w zakresie debaty polityczno-ustrojowej. Dlatego szczególnie ostre kontrowersje rodzą się na tle działań podejmowanych imieniu i na rzecz instytucji publicznych. Przede wszystkim dotyczy to stosowania sankcji (prawnych lub społecznych) wobec jednostek, których poglądy nie odpowiadają rozpowszechnianemu przez te instytucje systemowi oceniania i uzasadniania ocen. W tak sformatowanym społeczeństwie brak bowiem miejsca na tolerancję i twórczą niezależność.

Z drugiej strony, ochrona konstytucyjnie uzasadnionych interesów indywidualnych i społecznych uniemożliwia akceptację stanowiska, zgod-

1 Zgodnie z etymologią słowa tolerancja (łac.) tolerować to 'znosić coś'; tolerancja nie ma jednoznacznie pozytywnych konotacji, stąd nie należy go utożsamiać z takim pojęciami jak: akceptacja, zgoda czy wyrażenie uczucia solidarności. 
nie z którym wolność wypowiedzi w sferze obyczajowej miałaby wymiar absolutny, a wszelkie jej ograniczenia byłyby bezpodstawne.

W sumie mamy do czynienia ze złożonym konfliktem wartości, w którym przesłanki o charakterze emocjonalnym łatwo przeważają nad racjonalną argumentacją, a charakterystyczna terminologia wartościująca, typu: szkodliwy, zły, diabelski czy moralnie naganny świadczy o ich aksjologicznym uwarunkowaniu. Rodzi to liczne wątpliwości w formułowaniu i interpretacji podstawowych pojęć. Jednocześnie zauważa się, że granice między tym, co zakazane a tym co dozwolone ${ }^{2}$ odzwierciedlają obyczajowość kształtującą się w określonych społeczeństwach, w danym momencie ich rozwoju. W rezultacie granice legalności mają elastyczny charakter i podlegają stałym zmianom. Jest to zjawisko społeczne i prawne towarzyszące rozwojowi, wielokulturowych metropolii Europy. W tym kontekście nowe media masowego komunikowania, w szczególności Internet pełnią funkcję katalizatora zachodzących przemian.

Przedmiotem niniejszego artykułu jest wpływ nowych mediów na zasady harmonizacji wolności wypowiedzi i społecznej tolerancji. W tym kontekście rozważane są interakcje między swobodą ekspresji użytkowników Sieci a całokształtem współczesnych norm obyczajowych. Dyskusji poddano też nowe możliwości regulacji wolności słowa. Dotyczy to zarówno prawnych, jak i technicznych instrumentów regulacji.

\section{Obyczajność społeczna a potencjał komunikacyjny Internetu}

W wielokulturowym środowisku użytkowników Internetu łatwo jest dostrzec relatywność pojęć ocennych związanych ze sferą obyczajową. Wyraz temu zjawisku dają m.in. wypowiedzi internautów ankietowanych przez N. Tomosaitis ${ }^{3}$. Równocześnie elementy charakterystyczne dla ko-

2 Np. między pornografią a uznaną za sztukę erotografią. Por. M. Filar, Pornografia, „Przegląd Ustawodawstwa Gospodarczego” 1993, nr 8-9.

3 Zob. m.in. wypowiedź jednego $\mathrm{z}$ respondentów: „Zbytnim uproszczeniem byłoby lekceważenie tego alternatywnego typu rozmowy [...]”. „Internet jest miejscem, gdzie ludzie z całego świata mogą wymieniać opinie na tak delikatne tematy, jak np.: ludzka seksualność." (respondent - student MIT-u), N. Tomosaitis, Zagadnienia prawne na froncie elektronicznym, w: Seks w Internecie, Indianapolis USA, wydanie polskie: Warszawa 1998. Por. I. T. Miecik, Polska rozmowa internetowa. Raport polityki, Polityka 11/2005, s. 3 i n. 
munikowania w Sieci mają swoje odzwierciedlenie w dokonujących się przemianach społecznych.

Wzrost społecznego znaczenia nowych technik komunikacyjnych w sferze ludzkich interakcji był wyrazem szerszego procesu przemian kulturowych związanych $\mathrm{z}$ rozwojem społeczeństwa informacyjnego. W ramach tego procesu nowe formy ekspresji (charakterystyczne dla środowisk, które jako pierwsze korzystały z Sieci) zostały przejęte przez kulturę masową. Przy czym proces wchłaniania nowych elementów wiązał się z przekształceniem ich aspektów kontr- kulturowych w „sub”-kulturowe lub ,pop"-kulturowe, tak by były one łatwiejsze do rozpowszechniania na oficjalnym rynku informacji, rozrywki i reklamy.

W tym kontekście znamienny wydaje się kierunek zmian tworzonej w latach 80-tych literatury cyberpunkowej. Jeszcze wyraźniej kształtuje się omawiany proces w odniesieniu do rozwiniętej na początku lat 90 . kultury techno. Podobnie jak w komunikowaniu on-line wyróżniały ją tendencje do zacierania granic między ludźmi różnych ras czy płci. Jednym z filarów wskazanej tendencji był styl, który umożliwiał zarówno kobietom, jak i mężczyznom wykorzystanie podobnych środków ekspresji w tworzeniu własnego wizerunku. W szczególności w wielokulturowych, skupiskach miejskich noszone przez młodych ludzi ubiory przestały odpowiadać tradycyjnie pojmowanym różnicom ${ }^{4}$. Podobnie zaczęto traktować wyznaczniki rasowe: zarówno ciemnoskóra, jak i biała młodzież jest skłonna farbować włosy, zmieniać kolor oczu (szkła kontaktowe), przejść trwałe operacje plastyczne. Ten zewnętrzny wyraz negacji wobec tradycyjnych podziałów społecznych, czy nawet fizycznych uwarunkowań człowieka został zaakceptowany przez rynek mass mediów w postaci estetycznego eklektyzmu ${ }^{5}$. Obecnie funkcjonuje on w oficjalnej sferze obyczajowości i szeroko rozumianej kulturze. Jednak wbrew oczywistej sile

${ }^{4}$ Por. Cz. Miłosz, Kultura masowa, wybór, przekład, przedmowa, Kraków 2002, s. 11. Cenna wydaje się w tym miejscu uwaga R. Kapuścińskiego, zgodnie z którym „Dziś żyjemy w okresie przechodzenia od społeczeństwa masowego do nowego - planetarnego. Wiele temu sprzyja - rewolucja elektroniczna, niebywały rozwój wszelkiej komunikacji wielkie ułatwienia $\mathrm{w}$ łączności i przemieszczaniu się, a także - i $\mathrm{w}$ związku z tym - przeobrażenia zachodzące w świadomości pokoleń i w szeroko rozumianej kulturze. Spotkanie z Innym jako wyzwanie XXI wieku, wykład wygłoszony 1.10.2004 z okazji przyznania tytułu doktora honoris causa Uniwersytetu Jagiellońskiego.

Zob. uwagi F. Fukuyamy dotyczące możliwości, jakie w tym zakresie może stwarzać eugenika, Koniec człowieka, Kraków 2004, s. 128 i n. 
relatywizowania tego, co sankcjonowały tradycyjne normy, nie jest to wyraz kontrkulturowego protestu, lecz zjawisko o indywidualnym, komercyjnym i ludycznym charakterze. Należy też zauważyć, że brak ideologicznego pierwiastka buntu nie osłabia siły jego oddziaływania. W tym kontekście nowe media są elementem stymulującym zaznaczony proces przekształceń obyczajowych ${ }^{6}$.

W przestrzeni cybernetycznej inwencja twórcza człowieka obejmująca sferę kreowania własnej osobowości znajduje nadzwyczaj szerokie możliwości rozwoju ${ }^{7}$. Przesłanką determinującą specyfikę wypowiedzi rozpowszechnianych w Sieci oraz powstających w ich wyniku relacji międzyludzkich jest brak podstawowych - fizycznych elementów realnego komunikowania. Precyzując tę myśl należy zauważyć, że sztuczność wirtualnego środowiska jest na tyle oczywista, że zamiast tamować ludzką ekspresję, staje się jej swoistą zaletą. Wspólnie ze swobodą wypowiedzi stanowi element inspirujący do takiego kształtowania treści i formy wypowiedzi, który w interakcjach międzyludzkich pozwalają przezwyciężać ograniczenia systemu informatycznego. Obejmuje ona również przypisane człowiekowi wyznaczniki takie, jak: wiek czy kolor skóry, a często nawet płeć. W Sieci mają one charakter „niewiadomej” i odgrywają taką rolę, jaką im nadaje zainteresowana osoba. Parafrazując intelektualnie prowokacyjną myśl Oskara Wilde'a można powiedzieć, że maski, które Internauci noszą, są najciekawszym ich dziełem.

Podobnie jak dla uczestników grup dyskusyjnych możliwość autokreacji przez zmianę wizerunku staje się istotnym instrumentem ekspresji twórców i odbiorów współczesnej kultury masowej. Jest to najbardziej widoczne wśród młodego pokolenia europejskich (podobnie jak amerykańskich czy kanadyjskich ${ }^{8}$ ) metropolii, w których splatanie się róż-

6 Por. serwisy internetowe popularnych stacji muzycznych i pism młodzieżowych np. Music Television - www.mtv.com, „Wired Magazine” - www.wired.com. Zob. też nowe tendencje w sztuce - Ars Electronica 2005 Linz (Austria) - odbywający się co roku w festiwal sztuki, technologii i społeczności elektronicznej. Od 1987 r. organizatorzy przyznają nagrody Prix Ars Electronica, w dziedzinie sztuki elektronicznej i interaktywnej, animacji komputerowej, kultury cyfrowej i muzyki elektronicznej. www.aec.at.

7 Wypływa to z cech, jakimi charakteryzuje się komunikowanie w globalnej sieci komputerowej.

${ }^{8}$ Przesłanka wielokulturowości jest od lat siedemdziesiątych XX w. istotnym wyznacznikiem polityki wewnętrznej państwa w USA, a zwłaszcza w Kanadzie, niemniej jej implikacje rodzą też pewne wątpliwości, np.: czy nie pozbawia ona tożsamo- 
nych kultur stanowi element codziennych interakcji. W rezultacie współoddziaływanie przedstawionych wyżej procesów wydaje się mieć w globalnym tyglu kulturowym szczególnie podatny grunt. Wraz z rozpowszechnianiem się nowych mediów i związanych z nimi sposobów ekspresji, pluralizm, relatywizm oraz eklektyzm konwencji estetycznych oraz wzorców obyczajowych staje się coraz silniejszym, a zarazem bardziej uznawanym zjawiskiem społecznym ${ }^{9}$. Podobnie wyznaczona przez specyfikę komunikowania w Sieci obyczajowość jej użytkowników w sferze osobistych oddziaływań podlega stopniowej akceptacji przez środowiska określające wzorce kultury masowej ${ }^{10}$.

Przestrzeń cybernetyczna staje się (relatywnie) coraz rzadziej ${ }^{11}$ tematem utworów, które mogą być taktowane jako artystyczna prowokacja obyczajowa. Przeciwnie, są to materiały przeznaczone do rozpowszechniania w powszechnie reklamowanych kanałach informacji i rozrywki.

ści kanadyjskiej wspólnego rdzenia, czy nie utrudnia asymilacji, czy nie stanowi trudności w utrzymaniu jednego państwa, i czy utrwala podziały społeczne. Brak oficjalnej kultury oznaczał dla wielu Kanadyjczyków brak wspólnego systemu wartości i wnosił na piedestał autorytetu kulturowy relatywizm. Zob. T. Wróbel, A. Wróbel, Kanada, Warszawa 2000, s. 247. Podobne problemy mogą pojawić się również w UE, jeśli kultury narodowe zaczną zanikać, a ich miejsca nie zastąpią równie cenne, wspólne wartości.

9 Nie oznacza to jednak, że powyższy proces nie napotyka żadnych sprzeciwów społecznych. Zob. wypowiedź N. Postmana dotycząca systemu edukacji dzieci i młodzieży „ruch fundamentalistów (kiedyś zwany Moral Majority) lepiej zdawał sobie sprawę z upadku dzieciństwa niż wszystkie inne ugrupowania polityczne. Jego próby zorganizowania bojkotu ekonomicznego sponsorów pewnych programów telewizyjnych, przywrócenia zakazów i szacunku dla seksualności, stworzenia szkół kładących nacisk na rygorystyczne standardy uprzejmości są przykładem programu ukierunkowanego na zachowanie dzieciństwa". N. Postman, Building the Bridge to the XVIII Century. How the Past Can Improve the Future, New York 1999, wyd. polskie: W strone XVIII stulecia, Warszawa 2001, s. 140. Zob. Hustler Magazine Inc. v. Moral Majority, 796 F.2d, 1148 (9th Cir. 1986). Por. też inicjatywy Center For Media Education, http://www.cme.org/children/index_chld.html. Są one wyrazem dylematów, przed jakimi staje współczesny prawodawca.

${ }_{10}$ Powyższe tendencje są przedmiotem zainteresowania MacLuhan Centre w Toronto. http://mcluhan.utoronto.ca/projects.html, zob. New Media-Forum prowadzone w ramach McLuhan Program E-Lab http://www.newmedia-forum.net. Z perspektywy feministycznej, a zarazem mniejszości etnicznej interesująco wskazany aspekt przedstawia S. Willis w I shop therefore I am, w: Feminism (antologia), R. R. Warhol, D. P. Herndl, New Brunswick-New Yersey 1997.

${ }_{11}$ Relatywnie, w powyższym kontekście: stosunkowo do całości rozpowszechnianych treści. 
W tej mierze spełniają one odpowiednie kryteria zarówno, co do formy (produkcje przemysłu filmowego, reklamowego, muzycznego itp.), jak i co do treści (przedstawiają komunikowanie w przestrzeni cybernetycznej jako działalność zwykłych ludzi). Pełnią zatem podwójną funkcję: stanowią świadectwo roli, jaką Internet zaczął odgrywać w powszechnym odczuciu mieszkańców Europy i Ameryki Płn. oraz wzmacniają społeczną akceptację dla związanych z Internetem wzorców ekspresji ${ }^{12}$. Rzeczywiście można sądzić, że każdy użytkownik Internetu w sposób mniej lub bardziej świadomy akceptuje swoje działanie w platońskiej jaskini, w której ludzie przybierają postać cieni. Jednak cienie cyfrowej jaskini nie stanowią wiernego odbicia fizycznej postaci. W tym kontekście interesująca może być opinia jednego z użytkowników grup dyskusyjnych typu alt.sex, którego doświadczenia posłużyły N. Tomosaitis do szerszej psychologiczno-społecznej analizy sygnalizowanego w tym miejscu zjawiska. Badany stwierdził m.in.: „Jestem romantykiem, a więc naprawdę wierzę, że ten środek łączności będzie miał w nadchodzących latach dalekosiężny wpływ na relacje międzyludzkie"13. Przy czym potwierdzeniem przytoczonego przekonania ma być właśnie fakt, że: „Będąc daleko od siebie, każdy przed swoim ekranem komputerowym, musimy wchodzić w interakcje na zupełnie innym poziomie. Sądzę, że z tego powodu jest to całkowicie wyjątkowy sposób poznawania ludzi - wymagający, abyśmy 'wydobywali' swoje myśli i marzenia"'14.

Konkludując prowadzone w tej części rozważania, należy wskazać na jeszcze jeden kierunek współzależności między swobodą komunikowania a rozwojem infrastruktury informatycznej. Łatwość dostępu do materiałów o libertyńskich treściach była jedną z głównych przyczyn rozwoju nowych technik komunikowania w latach dziewięćdziesiątych. Dotyczy to zarówno postępu technicznego (rozwoju systemów typu video on demand), jak i rozpowszechnienia nowych mediów w szerokich, pozaakademickich środowiskach użytkowników. Do dzisiaj słowa odnoszące się do intymnej sfery kontaktów międzyludzkich sąjednym z najczęściej poszukiwanych haseł w Sieci, a związana z nim materia jednym z najbardziej

12 Znamiennym przykładem dla tych rozważań jest amerykańska super-produkcja filmowa z 1999 r. pt. Masz wiadomość. Zgodnie z opinią producenta L. S. Donner: „Sieć zapewnia nieograniczoną wolność i intymność [...]. Człowiek śmielej okazuje swoje uczucia aniżeli w zwykłej konwersacji”. Por. „Cinema, europejski magazyn filmowy" 1999, nr 07, s. 112.

${ }_{13}^{13}$ N. Tomosaitis, Zagadnienia, op. cit., s. 62.

14 Ibidem. 
popularnych tematów, podejmowanych w dyskusjach on-line. Fakt ten potwierdzają zgodnie autorzy serwisów informacyjnych największych anglojęzycznych przeglądarek, wyszukiwarek, katalogów stron WWW oraz pracownicy publicznych i prywatnych agencji zajmujących się analizą rynku internetowego ${ }^{15}$.

Z drugiej strony specjaliści - praktycy przemysłu reklamowego zwracają uwagę na skuteczność marketingu stosowanego przez podmioty prowadzące działalność w zakresie internetowej „rozrywki dla dorosłych” i proponują wykorzystywanie używanych przez nich technik w innych dziedzinach@-biznesu ${ }^{16}$. Problem polega na tym, że ekspansywność omawianej sfery komunikowania on-line, zwłaszcza firm podejmujących bezwzględną walkę o każdego klienta usług erotycznych wzbudza ostre kontrowersje społeczne ${ }^{17}$.

\section{Granice wolności wypowiedzi}

Bezkompromisowy immoralizm kampanii reklamowych ${ }^{18} \mathrm{w}$ powiązaniu z pluralizmem konwencji kulturowych i wzorców obyczajowych ro-

15 Zob. dane publikowane na portalach najbardziej popularnych przeglądarek, wyszukiwarek i katalogów stron WWW: Netscape, Internet Explorer, AltaVista, Lycos, Yahoo i in. Zob. też D. Orr, J. Ferrigno-Stack, Childproofing on the World Wide Web. A Survey of Adult Servers, 41, Jurimetrics J. 465 (2001), s. 467 i przedstawioną tam literaturę przedmiotu.

16 „Seks się sprzedaje, ale twórcy stron WWW z erotyczną zawartością opanowali do perfekcji sztukę marketingu, aby sprzedawać go jeszcze więcej. Przemysł rozrywkowy dla dorosłych może być [...] bardzo dobrym źródłem najlepszych praktyk marketingowych.” „,net - Magazyn Użytkowników Internetu” 2000, nr 03. Zob. też J. C. Levinson, Ch. Rubin, Marketing partyzancki on-line, wyd. polskie Warszawa 1998; S. Gaines, Goty zarobek, „The Guardian Europe”, 28.03.2002 (przedruk w „Forum” 18/2002 s. 26); I. T. Miecik, Polska rozmowa internetowa. Raport polityki, „Polityka" 2005, nr 11 s. 3 i n.

17 Wśród wielu reklamowych akcji prowadzonych przez tzw. „dot.com-y” szczególnie nagłośniona przez amerykańskie i kanadyjskie media była historia pary młodych ludzi, którzy postanowili stracić dziewictwo publicznie - w Internecie. Inicjacja miała być emitowana na żywo przez jedną z witryn amerykańskiej firmy Internet Entertainment Group (IEG). Do realizacji pomysłu nie doszło. Natomiast IEG, utrzymująca popularne i dochodowe witryny erotyczne, zdobyła wielu nowych klientów. Część z tych osób po raz pierwszy skorzystała z Internetu.

18 Istotne znacznie odgrywają w tej mierze działania marketingowe oraz reklama bezpośrednia. Por. bieżące dane Niezależnej Komisji ds. Nadzoru Standardu Usług Świadczonych za Pośrednictwem Sieci Telekomunikacyjnych (ICSTIS), www.icstis.org. 
dzi społeczne zapotrzebowanie na inicjatywy ustawodawcze zmierzające do wprowadzenia ograniczeń wolności wypowiedzi w Internecie. Niemniej akty normatywne w badanej materii powinny być nie tylko spójne w sferze aksjologicznej, ale także racjonalne w sferze praktycznej przede wszystkim nie mogą ignorować specyfiki środowiska, który regulują. Zlekceważenie tego elementu może być przyczyną, z powodu której podstawowe - dla zwolenników regulacji - ograniczenia prawne są pozbawione podstaw konstytucyjnych i jako takie muszą zostać w państwie prawa uchylone ${ }^{19}$.

Niemniej postulaty, by Internet pozostał sferą wolną od regulacji prawnych wydają się niemożliwe do realizacji ${ }^{20}$. Masowy rozwój nowych mediów rodzi potrzebę stanowienia prawa, którego normy zapewniałby ochronę podstawowych wartości konstytucyjnych. Dotyczy to zarówno wolności wypowiedzi, jak i konkurujących z nią wartości społecznych. Przynajmniej taki wniosek wypływa z orzecznictwa i zmian ustawodawczych podejmowanych w krajach Unii Europejskiej. Jednak, nowe inicjatywy legislacyjne mogą również wzbudzać poważne wątpliwości konstytucyjne. W tym kontekście podkreśla się, że sankcjonowanie tych norm może prowadzić do ograniczenia podstawowych wolności osobistych i obywatelskich. Dotyczy to przede wszystkim prawa do prywatności i anonimowości, jako niezbędnego filaru swobody wypowiedzi ${ }^{21}$. Jak wskazują dotychczasowe doświadczenia konstytucyjność nowego prawa jest podważana, gdy procesowi legislacyjnemu nie towarzyszy gruntowna analiza możliwości, jakimi dysponują osoby kształtujące i wykorzystujące techniczne środki komunikowania on-line. Są to zresztą podstawowe przyczyny znikomej skuteczności rozwiązań prawnych w środowisku cyfrowym.

Zgodnie z rozważaniami ujętymi w pierwszej części niniejszej pracy, przedmiot wypowiedzi rozpowszechnianych w Sieci jest bezpośrednio związany z połączenia indywidualnego i globalnego wymiaru komuniko-

19 Wyraźny obraz wskazanych zależności i wynikające z niego konsekwencje przedstawił SN USA w sprawie Reno v. ACLU, 521 US 843 (1997). Por. Harvard Law Review's Developments in the Law (praca zbiorowa) - The Law of Cyberspace, „Har. L.Rev." 1999, nr 112, s. 1575 i n.

20 A. Adamski, Przestępczość w Cyberprzestrzeni. Prawne środki przeciwdziałaniu zjawisku w Polsce na tle projektu konwencji Rady Europy, Toruń 2001; Konwencja w Sprawie Cyberprzestępczości, ETS no. 185 http://conventions.coe.int/EN/CadreListTreaties.htm.

21 Jest to związane ze stosowaniem systemów rejestracji użytkowników pragnących uczestniczyć w określonym forum lub korzystać z wybranego serwisu. 
wania. Wyrazem pierwszego jest osobisty charakter wrażliwości człowieka. Drugi podkreśla fakt, że normy determinujące granice wolność wypowiedzi w sferze obyczajowej cechuje znaczna rozbieżność ${ }^{22}$. Dlatego szczególnie znaczenie ma konsekwentne stosowanie podziału między wypowiedziami o znacznej szkodliwości społecznej a wypowiedziami uznanymi za nieprzyzwoite ze względów kulturowo-obyczajowych.

W odniesieniu do drugiej kategorii wypowiedzi, kluczową rolę należy przyznać argumentacji wolnościowej (wolności od) ${ }^{23}$. W tym kontekście na uwagę zasługuje stanowisko zgodnie z którym, nowe technologie umożliwiają upodmiotowienie użytkowników Internetu przez wzrost ich kontroli nad formą i treścią odbieranych przez nich przekazów. Oznacza to, że wolność wypowiedzi i wynikająca z niej odpowiedzialność powinny nabierać indywidualnego charakteru. Stosownie do tego założenia rozpowszechniane są wśród Internautów środki techniczne, które posiłkują się mechanizmami o charakterze zapobiegawczym. W zasadzie jest to system (auto)cenzury prewencyjnej. Do tej kategorii należą między innymi programy blokujące i filtrujące treści publikowane na stronach WWW lub przesyłane przez pocztę elektroniczną. Ważną funkcję pełnią też programy informatyczne mające chronić prywatność użytkowników Sieci. Jednak z perspektywy ochrony wolności wypowiedzi wdrażanie systemów zautomatyzowanej kontroli treści rodzi nowe, poważne zastrzeżenia (m.in. kto je wdraża, jakie są zasady selekcji treści, czy odbiorca końcowy jest o tym informowany, czy ich stosowanie jest obowiązkowe).

W sumie podstawowym problemem jest wskazanie takich mechanizmów normatywnych: prawnych lub pozaprawnych, które byłyby w pełni zharmonizowane z konstytucyjnie gwarantowanym zakresem wolności wypowiedzi. Dlatego stosowanie rozwiązań ustawowych i technologicznych nie należy traktować w kategoriach alternatywy rozłącznej. Moga się one uzupełniać, na zasadzie subsydiarności instrumentów technicznych względem regulacji prawnych.

22 Por. Miller v. California, 413 U.S. 15 (1973). W Europie, zob. np. stanowisko ETPC, który z sprawie Handyside przeciwko Wielkiej Brytanii podkreślił rolę odmienności i ciągłej zmiany poglądów w omawianej sferze. Handyside v. United Kingdom, Series A, no. 24, 1 EHRR 737 (1979).

23 Szerzej na ten temat I. Oleksiuk, Wolność wypowiedzi i wolność od wypowiedzi. Konflikt wartości w świetle rozwoju nowych mediów, w: Kulturowe instrumentarium wolności. Dziennikarstwo. Internet. Rynek, red. nauk. R. Paradowski, Poznań 2004, s. $149 \mathrm{i} \mathrm{n}$. 
Podejmując inicjatywy ustawodawcze w badanej materii, należy uwzględnić fakt, że zakres wolność wypowiedzi użytkowników Internetu jest uwarunkowany przez trzy przenikające się systemy norm. Pierwszy system został zarysowany we wstępnej części artykułu - tworzą go normy społeczne wyznaczające wzorce obyczajności i społecznej tolerancji. Drugi system zawiera tradycyjne normy prawne, obowiązujące na określonym terytorium i sankcjonowane przez przymus państwowy. Natomiast trzeci obejmuje normy należące do dynamicznie rozwijającego się systemu informatycznego.

Wskazane uwarunkowania implikują politykę legislacyjną opartą na ostrożnym harmonizowaniu środków i celów regulacji. W praktyce należy postulować, by cele ustawodawcze były możliwe do osiagnięcia, a wprowadzane dla ich realizacji ograniczenia konkurujących praw nie przekraczały wartości, jakie społeczeństwo informacyjne nadaje tym celom. Jednocześnie trzeba pamiętać, że wolność ekspresji to prawo osobiste gwarantowane konstytucyjnie dlatego stosowanie cenzury nie może służyć zaspokajaniu doraźnych gustów, choćby większości społeczeństwa. Wolność ekspresji i swobody twórczej, a także wolność korzystania z dóbr kultury nie mają charakteru absolutnego, jednak sankcja prawna jest demokratycznym państwie prawa ostatecznym instrumentem ochrony uznanych wzorców obyczajności. Dlatego nie wystarczy by inicjatywy ustawodawcze o cenzorskim charakterze uzyskały większość parlamentarną, ich autorzy muszą dostosować projekty aktów normatywnych do surowych w tej mierze wymogów konstytucyjnych.

\section{Summary}

The Internet, a network covering the majority of the world, changes the way we create and exchange information. What is its potential to change the way people interact and express themselves?

New media enable those with a particular interest to communicate with each other instantly, whatever the vehicle may be: chat lines, news groups, replies through email, or even browsing on each other's web sites. Individuals interested in very specific and obscure research can interact with people focusing on the same subject in another part of the world in no time. This provokes fast changes of sociopolitical notions and a greater variety of human endeavors. Can this be regarded as a benefit to mankind? The author discusses the potential of new media to transgress the traditional boundaries. What are the values that will need to be re-evaluated? Are we closer to a multicultural dialogue or rather to intercultural conflicts? Tolerance and censorship seem to be at the center of the controversy. 